\title{
Kinetics and mechanism studies in biomimetic chemistry: metalloenzyme model systems
}

\author{
Teddy G. Traylor \\ Department of Chemistry, D-006, University of California, San Diego La Jolla, California 92093 USA
}

\begin{abstract}
To understand the biological transport and utilization of dioxygen at the level of mechanistic chemistry it has been necessary to synthesize small molecules (active site sections) which carry out the binding or catalytic function. We have prepared iron porphyrin compounds which mimic the dioxygen binding to myoglobin and the oxidations catalyzed by peroxidases and related enzymes.

Using a combination of structural and environmental perturbations and millisecond to subpicosecond laser photolysis methods of following bimolecular or cage reactions we have established many of the factors which control dioxygen binding to heme proteins as well as details of cage processes in ligand binding to small molecules.

Additionally, effective catalysts for biomimetic oxidations have been developed and studied by kinetic methods. Studies of the effects of catalyst, oxidant and substrate structure and of environment on the rates of these catalytic processes have allowed mechanisms of epoxidation, hydroxylation and biomimetic suicide labelling to be determined.
\end{abstract}

\section{INTRODUCTION}

Dioxygen is transported and used in many biological systems through chemical reactions of heme proteins and other metalloproteins (ref. 1). The first protein crystal structures revealed that the active site for transport is an iron(II) protoporphyrin complex buried in the protein and attached through the iron to a protein base, often an imidazole of a histidine group (ref. 2). Later biochemical studies revealed that this same site carries out a variety of reactions, e.g. the reduction of hydrogen peroxide (ref. 3 ).

\section{MODEL SYSTEMS FOR BIOLOGICAL OXYGEN TRANSPORT}

Efforts to synthesize small molecule assemblies which duplicate the structure as well as the reactions of the heme proteins have taken two directions: preparation of stable five coordinated iron(II) porphyrin (heme) species and, simulation of the pocket in the protein with a large protecting group over or around the iron (ref. 4).

Our approach to these two objectives involved the synthesis of a protected porphyrin, a "cyclophane porphyrin" for the pocket (ref. 5) and covalent attachment of an imidazole to analogues of protoheme, systems we have called "chelated hemes" (ref. 6).

Dioxygen binding to hemes was first observed at low temperature (ref. 6) but in subsequent studies both steric protection, which prevents bimolecular self oxidation of iron(II) (e.g. picket fence hemes (ref. 7)) or capped hemes (ref. 8) and fast kinetic methods (ref. 9), in which kinetics and equilibria are easily measured before oxidation sets in, were used to study dioxygen binding. There are now many examples of superstructured hemes which form stable complexes with dioxygen at room temperature (ref. 4).

Extensive studies (ref. 4,10 ) in these several kinds of model systems have revealed the principal factors which can control dioxygen (and other ligand) binding. Table 1 summarizes the effects of solvent polarity, electron donation to the heme or the fifth ligand, steric hindrance, and hydrogen bonding.

Table 1. Effects of Structure and Environment on the Kinetic and Equilibrium Constants for Binding $\mathrm{O}_{2}$ and $\mathrm{CO}$.

\section{Environmental Change}

1. Electron Donating Group

2. More Polar Solvent or Nearby Group

3. Hydrogen Bonding to Ligand

4. Increased Steric Hindrance

\section{Resulting Effect on Constants ${ }^{\mathrm{a}}$}

\begin{tabular}{lll}
$\mathrm{CO}$ & $\mathrm{O}_{2}$ \\
$\mathrm{Off}$ & $\mathrm{Eg} \quad \mathrm{On} \quad \mathrm{Off}$ \\
\hline
\end{tabular}

$\begin{array}{cccccc}\text { On } & \text { Off } & \text { Eq } & \text { On } & \underline{\text { Off }} & \underline{\text { Eq }} \\ \text { N } & \text { N } & \text { N } & \text { N } & \text { D } & \text { I } \\ \text { N } & \text { i } & \text { d } & \text { N } & \text { D } & \text { I } \\ \text { N } & \text { N } & \text { N } & \text { N } & \text { d } & \text { i } \\ \text { D } & \text { N } & \text { D } & \text { D } & \text { N } & \text { D }\end{array}$
\footnotetext{
a On = association rate, $\mathrm{k}_{\mathrm{B}}^{\mathrm{L}} ;$ Off $=$ dissociation rate, $\mathrm{k}_{\mathrm{B}}^{\mathrm{L}} ; \mathrm{Eq}=$ equilibrium constant, $\mathrm{K}_{\mathrm{B}}^{\mathrm{L}} ; \mathrm{N}=$ no effect,
$\mathrm{D}=$ large decrease, $\mathrm{d}=$ small decrease, $\mathrm{I}=$ large increase, $\mathrm{i}=$ small increase.
}

This table suggests that, in the relative binding of $\mathrm{CO}$ or $\mathrm{O}_{2}$, the differentiation is accomplished by polar effects and not by steric hindrance. Although this conclusion has been subject to some controversy, due in part to the finding that both $\mathrm{CO}$ and $\mathrm{O}_{2}$ form bent complexes in proteins (ref. 11) but only $\mathrm{O}_{2}$ forms a bent complex with unhindered models (ref. 12), it seems to be generally accepted (ref. 13). The fast kinetic studies, described below also address this point. 


\section{Fast and very fast kinetics}

Recent studies of the photolysis of heme protein complexes of $\mathrm{CO}$ in low temperature glycerol/water glasses (ref. 14) or nsec to psec photolysis in solution (ref. 15) have revealed CO-independent fast processes. This prompted us to study fast processes with model systems (ref. 16). These studies have led us back to considerations of cage effects, formerly the realm of free radical or carbocation chemistry.

Photolyses of liganded hemes as model systems for heme proteins usually involve the attachment of two ligands to the iron, even if one is a solvent molecule (eq. 1). ( $\mathrm{L}=$ ligand, $\mathrm{Hm}=$ iron(II)porphyrin, $\mathrm{B}=$ a second ligand).

$$
\mathrm{LHmB} \frac{\mathrm{hv}}{\mathrm{k}_{\mathrm{B}}^{\mathrm{L}}} \mathrm{HmB}+\mathrm{L}
$$

In order to know what process is being observed after photolysis it is important to establish which of the $\mathrm{B}_{2} \mathrm{Hm}$, $\mathrm{L}_{2} \mathrm{Hm}, \mathrm{LHmB}$, etc. species is undergoing photolysis. Unlike metal carbonyls which are very slow in thermal dissociation (ref. 17) the heme complexes have relatively rapid dissociations. Therefore structure determination of LHmB in solution requires not only NMR studies etc., but knowledge of the dynamics and equilibrium constants. We have studied the kinetics of the deuteroheme-imidazole-CO system in detail (ref. 18) and can, with the aid of published equilibrium constants, assign all of the rate constants for this system where $B=$ imidazole and $L=C O$ or $R N C$.

\section{Diffusion and activation controlled ligations}

Photolysis of a 1-methylimidazole-heme-methyl isocyanide in toluene with a 0.4 psec laser pulse affords the transient spectra shown in Figure 1.

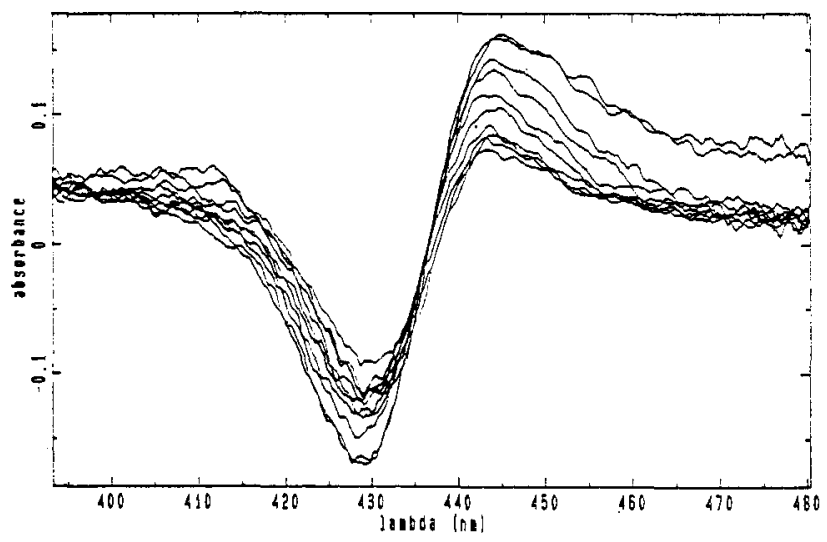

Figure 1.

A series of psec of spectra after photolysis in toluene. Times: $0,0,2,4,6,8,12,20,29,40$, and 50 psec.

The first difference spectrum corresponds to the spectral difference between BHmCNMe and BHm. The HmCNR species absorbs around $410 \mathrm{~nm}$ (ref. 19). Very similar spectroscopic evolutions are seen with the photolysis of the corresponding complexes of pyridines, tetrahydrofuran, isocyanides, and with dioxygen (in myoglobin)(ref. 20). No such spectroscopic evolution on the psec or nsec time scale is observed when the photolyzed ligand is carbon monoxide and the solvent toluene. Changing to the higher viscosity solvent glycerol does reveal this fast process although its rate constant, $\sim 10^{9} \mathrm{sec}^{-1}$, is smaller than those for the other ligands (ref. 21). This difference between $\mathrm{CO}$ and the other ligands had already appeared in the bimolecular rate constants, the $\mathrm{k}_{\mathrm{B}}^{\mathrm{L}}$ of eq. 1 being around $10^{7} \mathrm{M}^{-1}$ $\mathrm{sec}^{-1}$ for $\mathrm{CO}$ and $2 \times 10^{8} \mathrm{M}^{-1} \mathrm{sec}^{-1}$ for all other ligands. Apparently all the ligands bind at diffusion controlled rates except for $\mathrm{CO}$ (ref. 20,22). The $\Delta \mathrm{V}^{\ddagger}$ confirms this, showing a retardation of the reactions of imidazole and isocyanides and an acceleration of bond formation for $\mathrm{CO}$ (ref. 23) as the pressure is increased.

Our experimental findings are represented in Figure 2 where the exponential rates are expressed in three linear time scales $0-10^{-9} \mathrm{sec}, 10^{-9}-10^{-6} \mathrm{sec}$, and $10^{-6}-10^{-3} \mathrm{sec}$. With model systems we see two decays only (not counting the early excited state decay in about 2 psec), one having a rate constant near $10^{11} \mathrm{sec}^{-1}$ (contact pair return) and one which is bimolecular (external return). Similar rate constants are observed for all ligands except $\mathrm{CO}$ where the observed geminate rate constant at high viscosity is around $3 \times 10^{9} \mathrm{sec}^{-1}$ (ref. 21,24).
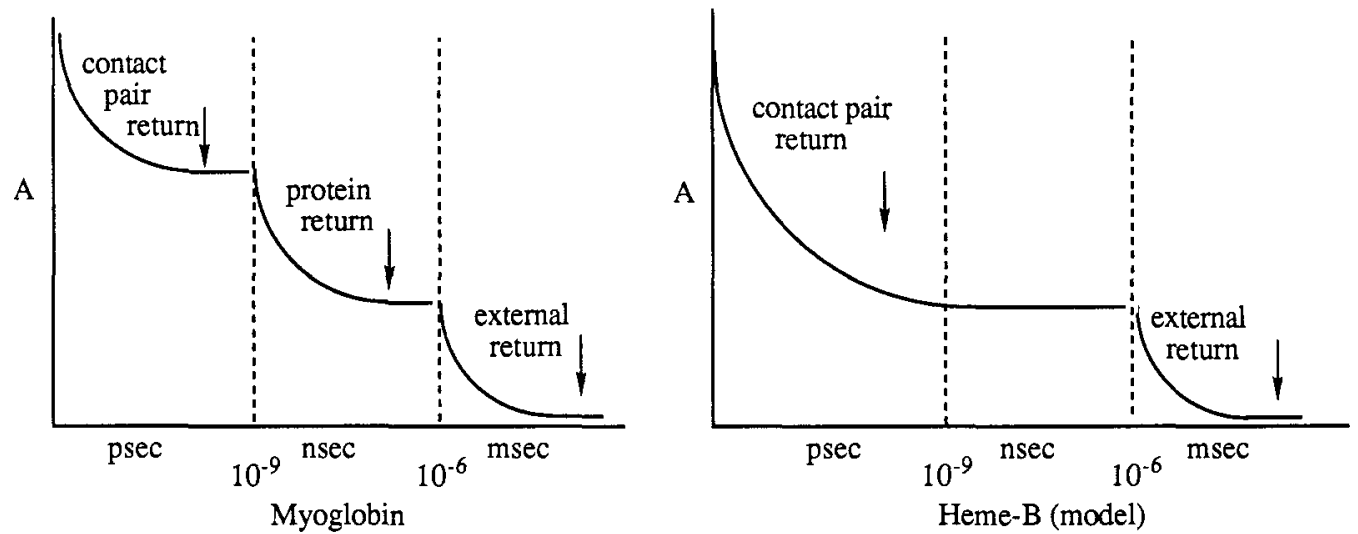

Figure 2. Representations of the changes in the $\mathrm{HmB}$ region after photolysis of $\mathrm{BHmL}\left(\mathrm{L}=\mathrm{RNC}, \mathrm{Im}, \mathrm{Pyr}, \mathrm{O}_{2}, \mathrm{NO}\right)$ 
Three-state and four-state mechanisms

With myoglobin and e.g. methyl isocyanide, three decays are seen with rate constants in the range of $10^{11} \mathrm{sec}^{-1}$, $10^{7} \mathrm{sec}^{-1}$ and a bimolecular rate measured as a pseudo first order rate constant (ref. 19). Following the model of Frauenfelder et al. (ref. 14a) for myoglobin we have explained these data by the 3 and 4-state schemes below.

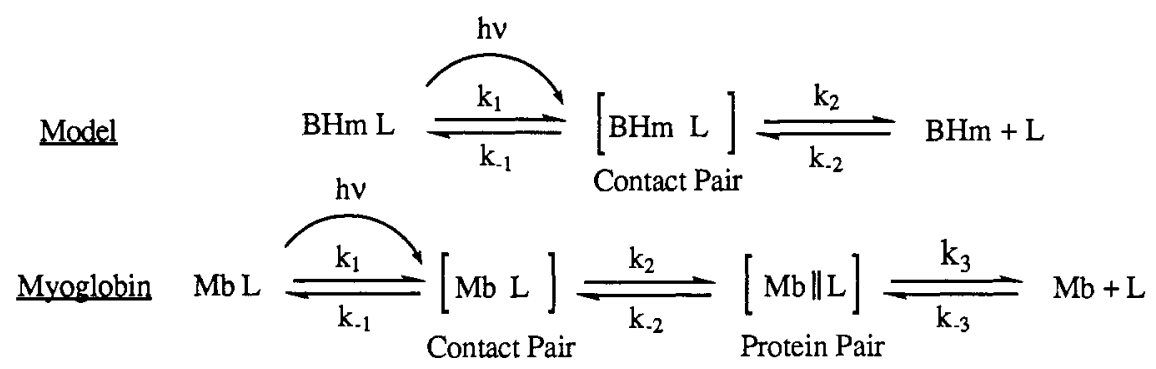

The most striking of our findings is that the collapse rate constant $\left(\mathrm{k}_{-1} \cong 5 \times 10^{10} \mathrm{sec}^{-1}\right)$ is very nearly the same for the model, for a hindered cyclophane (ref. 25), and for myoglobin using the rather large t-BuNC ligand. This means that there is no steric effect on the bond-making step, $k_{-1}$. Thus there is no distal steric effect of the type often discussed for myoglobin. The bending of carbon monoxide in myoglobin therefore has nothing to do with the slow rate in myoglobin as compared to isolated models. The differences occur mostly in k-3, $\mathrm{k}_{3}$, and $\mathrm{k}-2$, in external and protein return, not in contact pair return. Perhaps the term "migrational steric effects" better describes the retarded heme protein rates than does distal side steric effects (ref. 26). The conclusions here are the same as those of Table 1. Molecules of the same size and shape, e.g. CO, $\mathrm{O}_{2}$ and $\mathrm{NO}$, are not differentiated by steric effects at all since their diffusional properties are the same. But migrational steric effects retard the rates of these ligands and retard more severely the rates of binding of larger ligands.

\section{Cage wall collapse}

These systems provide a unique opportunity to study the effects of reactive cage walls (ref. 27). One example shows that contact pairs do not readily exchange with equally reactive ligands present in the solvent. Carbon monoxide has $\mathrm{k}-1=10^{9} \mathrm{sec}^{-1}$ and 1-methylimidazole has $\mathrm{k}-1=5 \times 10^{10} \mathrm{sec}^{-1}$. Photolysis of $\mathrm{CO}$ in pure 1-methylimidazole shows very little if any 1-methylimidazole return (wall collapse) in the psec time scale. A slower return $\mathrm{k}_{\mathrm{B}}^{\mathrm{B}} \cong 3 \times 10^{9} \mathrm{sec}^{-1} \mathrm{can}^{-1}$ be attributed to the bimolecular reaction which has a second order rate constant of $2 \times 10^{8} \mathrm{M}^{-1} \mathrm{sec}^{-1}$. In other systems, for example in tetrahydrofuran, reaction of the solvent with the heme exceeds the predicted bimolecular rate, suggesting some reaction with the contact pair. Fast solvent reactions with chromium pentacarbonyl have also been reported (ref. 17).

\section{MODEL SYSTEMS FOR BIOLOGICAL OXIDATIONS}

The discovery of cytochromes $\mathrm{P} 450$ which are capable of catalyzing epoxidation and hydroxylations of saturated hydrocarbons (ref. 28) stimulated the search for simple iron porphyrin systems which could mimic these reactions. This was accomplished, albeit in poor yield, by the groups of Groves (ref. 29) and Chang (ref. 30) in 1979 using chemical oxidants $\mathrm{YO}$ as shown below. There followed a number of studies directed at improvement of the efficiency of the model systems and at the understanding of the mechanisms of these two reactions (ref. 31).

$$
\mathrm{Hm}^{+}+\mathrm{YO} \stackrel{(4)}{\longrightarrow} \mathrm{Hm}^{+} \mathrm{O}+\mathrm{Y}^{-} \stackrel{\mathrm{RH}(5)}{\longrightarrow} \mathrm{Hm}^{+}+\mathrm{ROH} \stackrel{\text { Alkene (6) }}{\longrightarrow} \mathrm{Hm}^{+}+\text {epoxide }
$$

The species $\mathrm{Hm}^{+} \mathrm{O}$ has since been isolated at low temperature and studied by several spectroscopic methods by Groves and his collaborators (ref. 32) as well as others (ref. 33). The commonly accepted view of this structure (a biomimetic model of compound I of horseradish peroxidase) is a two electron-oxidized form of the iron(III) porphyrin having an $\mathrm{Fe}=\mathrm{O}$ bond and most of the positive charge on the porphyrin ring. This "iron(IV) radical cation" is symbolized here by $\mathrm{Hm}^{+} \mathrm{O}$ and its one electron reduced counterpart by $\mathrm{HmO}$ (an iron(IV) porphyrin with an $\mathrm{Fe}=\mathrm{O}$ bond). Our interests, like those of several other research groups, have centered upon studies of mechanisms by which oxidizing agents $\mathrm{YO}$, which do not carry out the reactions of interest, react with iron(III) porphyrins to produce either the $\mathrm{Hm}^{+} \mathrm{O}$ or $\mathrm{HmO}$ species and how these species accept an electron from the substrate or transfer an oxygen atom to it.

\section{Preparation of stable biomimetic catalysts}

The principal methods used in our laboratories have been kinetic studies of these processes. For kinetic studies of catalytic processes to be definitive two things are requisite. 1 . The catalyst must survive the reaction during kinetic measurements and be capable of high yield and high turnover catalysis. 2 . Kinetic methods which are convenient and rapid enough to detect intermediates are needed. Catalyst survival has been accomplished in two ways, each employed for a specific objective. Either the substrate is made much more sensitive to oxidation (eq. 7) than the catalyst itself or the catalyst is made more resistant to oxidation (eq. 8) than even the most stubborn substrate.

$$
\begin{aligned}
\mathrm{Hm}^{+} \mathrm{O}+\mathrm{S} & \stackrel{\mathrm{k}_{\mathrm{ox}}}{\mathrm{Hm}_{\text {des }} \mathrm{O}+\mathrm{Hm}^{+}} \stackrel{\mathrm{SO} \quad(\mathrm{S}=\text { substrate })}{\longrightarrow} \text { catalyst destruction }
\end{aligned}
$$


Table 2. Iron(III)tetraphenylporphyrins prepared as catalysts for hydroxylation reactions.

\begin{tabular}{ccccccccc} 
Cpd & Aryl & Porphine & Cpd & Aryl & Porphine & Cpd & Aryl & Porphine \\
$\mathbf{1}$ & $\mathrm{Ph}$ & $\mathrm{H}_{8}$ & $\mathbf{4}$ & $2,6-\left(\mathrm{CF}_{3}\right)_{2} \mathrm{C}_{6} \mathrm{H}_{3}$ & $\mathrm{H}_{8}$ & $\mathbf{7}$ & $2,6-\mathrm{Cl}_{2} \mathrm{C}_{6} \mathrm{H}_{3}$ & $\mathrm{~F}_{7}, \mathrm{H}$ \\
$\mathbf{2}$ & Mesityl & $\mathrm{H}_{8}$ & $\mathbf{5}$ & $2,6-\mathrm{Cl}_{2} \mathrm{C}_{6} \mathrm{H}_{3}$ & $\mathrm{Br}_{8}$ & $\mathbf{8}$ & $\mathrm{C}_{6} \mathrm{~F}_{5}$ & $\mathrm{Cl}_{8}$ \\
$\mathbf{3}$ & $2,6-\mathrm{Cl}_{2} \mathrm{C}_{6} \mathrm{H}_{3}$ & $\mathrm{H}_{8}$ & $\mathbf{6}$ & $\mathrm{C}_{6} \mathrm{~F}_{5}$ & $\mathrm{H}_{8}$ & $\mathbf{9}$ & $\mathrm{C}_{6} \mathrm{~F}_{5}$ & $\mathrm{~F}_{8}$ \\
\hline
\end{tabular}

We have accomplished the catalyst stabilization of iron tetraphenylporphyrins toward reaction 8 by substituting halogens for some or all of the phenyl hydrogens (ref. 34). A few of these catalysts are shown in Table 2 . Their stability toward oxidative destruction increases in the order $\mathbf{1} \rightarrow \mathbf{8}$.

As an example of the stability achieved, in the oxidation of cyclohexane.at low conversion, a $93 \%$ yield of cyclohexanol with only $2.5 \%$ cyclohexanone is obtained without catalyst loss, using catalyst $\mathbf{5}$. Clearly, kinetic studies of this reaction are possible with this catalyst. By comparison, iron(III) tetraphenylporphyrin affords only a few percent yield and is completely destroyed under these conditions.

\section{Kinetic methods in catalytic oxidations}

For studies of the effects of hemin structure on rates of reaction we have searched for sensitive substrates which have convenient spectroscopic changes upon oxidation as well as oxidants which have similarly convenient spectroscopic changes upon reduction (ref. 35a). Following the disappearance of the oxidant or the substrate alkenes (eq. 9) provides accurate psuedo first order plots which give the same first order rate constant even at, for example, the same concentration of the oxidant and the alkene (ref. $35 \mathrm{~b}$ ).

$$
\mathrm{Hm}^{+}+\mathrm{RIO}(\text { alcoholate })+\mathrm{Ph} \longrightarrow \mathrm{Ph} \stackrel{\mathrm{k}_{\mathrm{obs}}}{\longrightarrow}
$$

This finding and extensive studies of concentration dependence (ref. 35) reveal that the kinetics of these reactions are invariably independent of substrate structure or concentration in homogeneous solutions, even if the substrate is an alkane. For example the rate of reaction of perfluoroiodosylbenzene (PFIB), followed by changes in its absorbance at $280 \mathrm{~nm}$, is exactly the same (ref. 36) whether the substrate is $0.01 \mathrm{M}$ or $1 \mathrm{M}$ norbornene or $1 \mathrm{M}$ norbornane, using a catalyst 5 which is known to catalyze oxidation of both substrates in high yield (ref. $34 \mathrm{~b}$ ).

$$
\mathrm{Hm}^{+}+\mathrm{PFIB}+
$$

Rates of oxidation by all oxidants we have used, $\left(\mathrm{RCO}_{3} \mathrm{H}, \mathrm{ROOH}, \mathrm{RIO}\right)$ with a wide variety of catalysts follow the kinetic expression below (ref. 35).

$$
-\frac{\mathrm{d}[\mathrm{Ox}]}{\mathrm{dt}}=\frac{\mathrm{d}[\text { product }]}{\mathrm{dt}}=\mathrm{k}_{\mathrm{obs}} \cdot\left[\mathrm{Hm}^{+}\right][\mathrm{Ox}]
$$

\section{Effects of hemin structure and environment on rates}

The reaction of oxidants such as peracids, hydroperoxides or iodosylbenzenes with iron(III) porphyrins could produce either $\mathrm{Hm}^{+} \mathrm{O}$ by a heterolytic cleavage (eq. 15) or $\mathrm{HmO}$ by a homolytic cleavage (eq. 14). The oxidant can reasonably be expected to attach to the iron before cleavage and there is now compelling evidence that this is a reversible step $\left(K_{1}\right)$ of eq. 13 (ref. 37).

$$
\begin{aligned}
\mathrm{Hm}^{+} \mathrm{X}^{-}+\mathrm{ROOH} & \stackrel{\mathrm{K}_{1}}{\mathrm{H}} \mathrm{Hm}^{+} \mathrm{OOR}+\mathrm{X}^{-} \text {or } \mathrm{HmOOR}+\mathrm{HX} \\
\mathrm{HmOOR}+\mathrm{HX} \stackrel{\mathrm{k}_{2}}{\longrightarrow} \mathrm{HmO}+\mathrm{RO} & \mathrm{Hm}^{+} \mathrm{O}+\mathrm{ROH}\left(\text { or } \mathrm{RO}^{-}\right)+\mathrm{X}^{-}
\end{aligned}
$$

When HmOOalkyl is produced at low temperature in aprotic solvents or under very basic conditions, the products of decomposition suggest homolytic cleavage (reaction 14) (ref. 38). However, in hydroxylic solvents all three classes of oxidants we have used appear to react by heterolytic cleavage (reaction 15). This is evidenced by the products obtained (epoxides from alkenes, alcohols from $\mathrm{ROOH}$ ) and by the response of the rates to changes in structure or medium (ref. 39).

We have determined the effect of electron donation to the hemin upon rates of reaction with pentafluoroiodosylbenzene (ref. 40). The fact that electron donating substituents increase the rate of oxidation while decreasing the equilibrium constant corresponding to $\mathrm{K}_{1}$ of eq. 13 , by making the iron(III) less electrophilic shows that the rate limiting step in this process is the breaking of the I - O bond (ref. 39a,40a). 
A comparison of rates of reaction of hydroperoxides with either chelated protohemin, having an attached imidazole, or protohemin dimethyl ester chloride reveals a rate increase of about 100 -fold in methylene chloride and about sixtimes in methanol upon attachment of the imidazole (ref. 39). The use of an internally hydrogen bonded imidazole instead of an alkylimidazole provides a further increase in rate, indicating that hydrogen bonding increases the ability of imidazole to supply electron density to the hemin (ref. 40b).

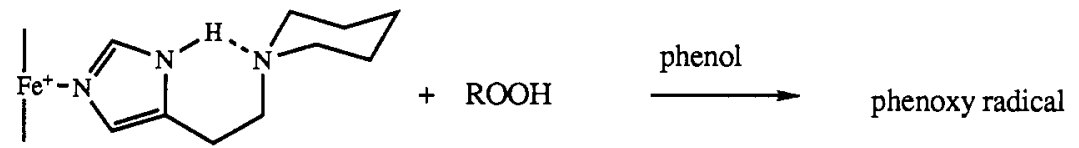

We have found that rates of reactions of peracids and hydroperoxides with chelated protoheme (eq. 17) in hydroxylic solvents such as methanol or methanol/water increase with increasing stability of the leaving group. The rates follow Taft's $\sigma^{*}$ values of $\mathrm{R}$ for the product $\mathrm{ROH}$ or $\mathrm{RCO}_{2} \mathrm{H}$.

$$
\mathrm{Hm}^{+}+\mathrm{ROOH} \frac{\mathbf{k}_{\text {obs }}}{\text { phenol }} \text { phenoxy radical }+\mathrm{ROH}
$$

Buffer catalysis of the reactions of hemin with peracids and hydroperoxides in aqueous alcohols has been observed in our laboratories (ref. 39) and in those of Lee and Bruice (ref. 41), as exemplified by Figure 3 for the reaction of hydrogen peroxide $\left(10^{-4} \mathrm{M}\right)$ with microperoxidase $\left(3 \times 10^{-7} \mathrm{M}\right)$ in collidine buffers at $\mathrm{pH}=7.5, \mathrm{pD}=8.2$ in an aqueous methanol (80:20 water to methanol by volume).

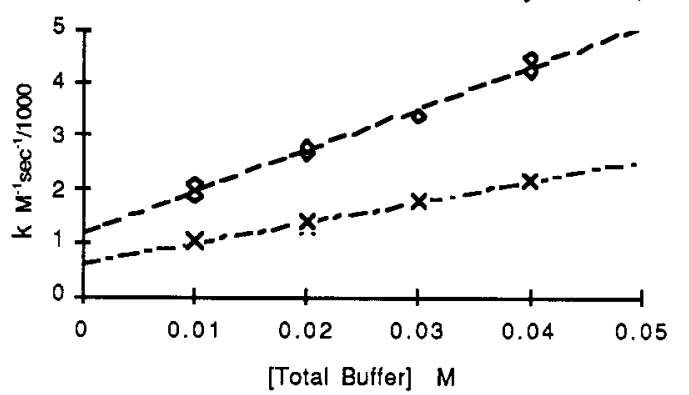

Figure 3. Plots of second-order rate constants for the reaction of microperoxidase with hydrogen peroxide as a function of total buffer concentration. (Protic solvent, $\diamond$; deuterated solvent, $x$ ).

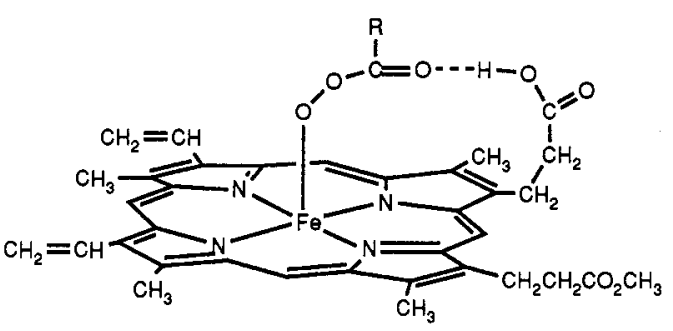

Figure 4. Structure of a possible transition state for internal catalysis of the reaction of peracids with protohemin derivatives.

We have found that alcohols and water are themselves general acid catalysts for the reactions of hydroperoxide (ref. 39a). This is seen in both the plots of rate versus alcohol acidity and by the solvent deuterium isotope effects of around two for both the slopes (buffer catalysis) and intercepts (solvent catalysis)(Figure 3).

The proximal juxtaposition of the acid catalyst, thought to be important in horseradish peroxidase catalysis is shown in Figure 4 (ref. 39a,40a).

Such internal acids increase rates by large factors in nonpolar environments like methylene chloride where solvent catalysis is absent. In methanol the effect is smaller. This explains the failure to observe general acid catalysis in water (ref. 41) which is itself a general acid catalyst.

\section{Mechanisms of hemin reactions}

The reactions of peracids, hydrogen peroxide, hydroperoxides and iodosylbenzenes with iron(III) porphyrins can therefore be summarized as shown in Scheme 1 below. Taken together, these data cannot be reconciled with homolytic cleavage in hydroxylic solvents.

\section{Scheme I}

The Common Heterolytic Reaction.

$$
\text { Mechanism for Reactions of Oxygen Atom Donors with Iron(III) Porphyrins }
$$

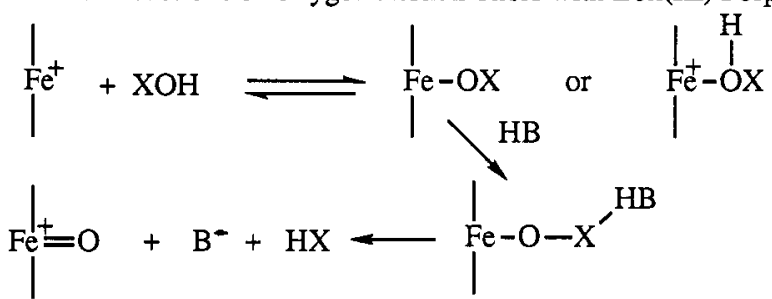

Furthermore, they provide strong evidence for the general acid catalyzed reactions of hydrogen peroxide with peroxidases (ref. 42) and catalase (ref. 43) and for the catalysis by either water or the nearby threonine hydroxyl group in cytochrome P450 (ref. 44).

\section{Reactions with alkenes: epoxidation and $\mathrm{N}$-alkylation of the catalyst}

The rate law of equation 12 , while useful in the study described above, provides no evidence concerning any substrate oxidation reaction (see eq. 18). For the oxygen transfer step and accompanying processes we must rely upon competitive kinetic methods (ref. 45). However, this procedure might fail to reveal transient species, with consequent 
errors in mechanistic conclusions.

$$
\mathrm{Hm}^{+} \mathrm{O}+\underset{\mathrm{C}=\mathrm{C}}{\mathrm{C}} \stackrel{\mathrm{fast}}{\longrightarrow} \stackrel{\mathrm{C}-\mathrm{C}}{/}+\mathrm{Hm}^{+}+\text {other products }
$$

We have nevertheless used spectroscopic methods as well as product isolation techniques to determine relative reactivities of alkenes. Comparisons of these two methods affords some interesting information. In the competitive reactions of two alkenes with the $\mathrm{Hm}^{+} \mathrm{O}$ intermediate we can calculate relative rates in two ways $\left(S_{1}=\right.$ alkene $1, S_{2}=$ alkene 2). We can obtain relative rates from the ratio of products (ref. 45) or from the effect of $S_{2}$ on the yield of $S_{1} \mathrm{O}$

$$
\begin{aligned}
& \mathrm{Hm}^{+} \mathrm{O}+\mathrm{S}_{1}+\mathrm{S}_{2} \longrightarrow \mathrm{S}_{1} \mathrm{O}+\mathrm{S}_{2} \mathrm{O} \\
& \text { (Set concentrations of } S_{1} \text { the same as } S_{2} \text { ) } \\
& \text { Product Method: } \frac{\mathrm{k}_{\mathrm{s} 1}}{\mathrm{k}_{\mathrm{s} 2}}=\frac{\mathrm{S}_{1} \mathrm{O}}{\mathrm{S}_{2} \mathrm{O}} \\
& \text { Kinetic Method: } \frac{\mathrm{k}_{\mathrm{s} 1}}{\mathrm{k}_{\mathrm{s} 2}}=\frac{\left[\mathrm{S}_{1} \mathrm{O}\right]_{\operatorname{mix}}}{\left[\mathrm{S}_{1} \mathrm{O}\right]_{\mathrm{S}_{2}=0^{-}\left[\mathrm{S}_{1} \mathrm{O}\right]_{\operatorname{mix}}}}
\end{aligned}
$$

The product method is generally accomplished by gas chromatographic analysis (ref. 45,46). The kinetic method can also be done this way, but the convenient method uses as $S_{1}$ an alkene such as 1,4-diphenylbutadiene (DPBD) whose absorbance loss can be followed, as illustrated in Figure 5 (ref. $35 \mathrm{~b}$ ).

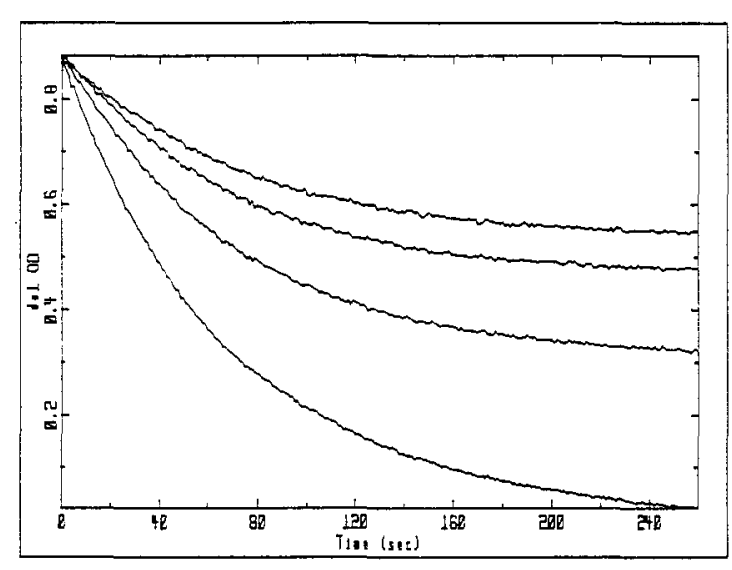

Figure 5. Plots of DPBD absorbance (del OD at $348 \mathrm{~nm}$ ) vs time for competitive epoxidation of 1,4-diphenylbutadiene $\left(S_{1}\right), 3 \times 10^{-5} \mathrm{M}$ and cis-2-trans-4-hexadiene $\left(S_{2}\right)$ $\left(0,17,22,25 \times 10^{-5} \mathrm{M}\right)$ with PFIB at $10^{-6} \mathrm{M}$ in hemin 3 .

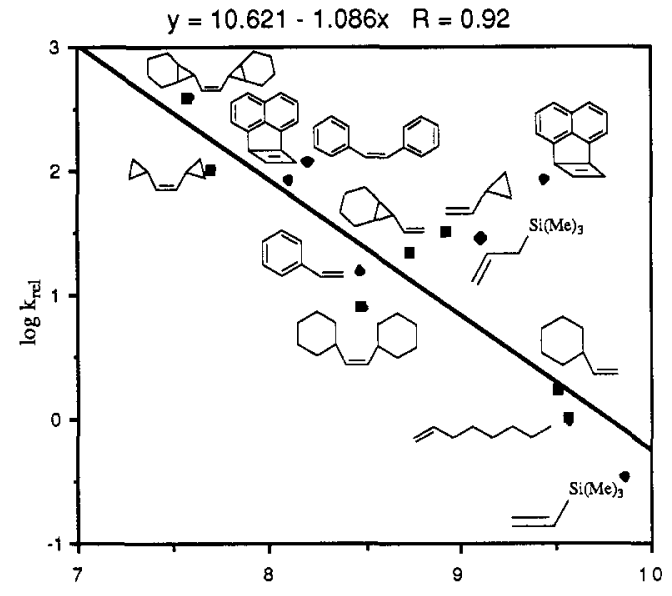

Figure 6. A plot of $\log \mathrm{k}_{\mathrm{rel}}$ for the reactions of various alkenes with the high valent intermediate against alkene ionization potentials. The $k_{\text {rel }}$ were obtained as in Figure 5.

The relative rates can be calculated from the initial slopes or from the infinity point $\left(\mathrm{S}_{1} \mathrm{O}\right.$ yield). These two methods usually give the same result. For example norbornene, which affords quantitative epoxidation yields, gives the same result by either method.

Using the kinetic method we have established that the relative rates correlate with alkene ionization potentials (ref. $35 \mathrm{~b}$ ). An example of this correlation is seen in Figure 6 (ref. 47).

Several interesting points are revealed here. First, the reaction rate is increased by $\sigma-\pi$ conjugation of both the cyclopropyl group and the $-\mathrm{CH}_{2} \mathrm{SiMe}_{3}$ group which have $\sigma^{+}$values of -0.5 and -0.6 respectively (ref. 48). Secondly vinyltrimethylsilane, which is activated toward electrophilic attack (ref. 49) as is allyltrimethylsilane, is nevertheless even slower to react than are 1 -alkenes. The activation of vinyltrimethylsilane by $\sigma-\pi$ conjugation requires a rotation of the carbon-metal bond. The low observed reactivity is strong evidence against direct electrophilic attack, which would result in strong $\sigma-\pi$ conjugation.

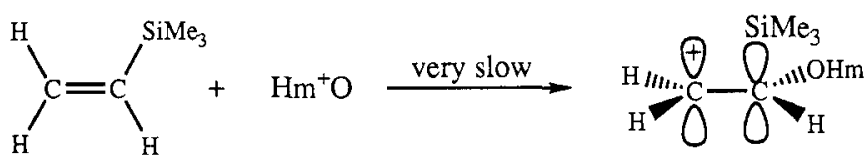

Additionally, the acceleration provided by the second cyclopropyl group in 1,2-dicyclopropyl alkenes argues strongly against a direct electrophilic attack which would prevent $\sigma-\pi$ conjugation of the second cyclopropyl (or phenyl in cisstilbene) group. But these findings are well accommodated by the electron transfer mechanism or the direct three center oxygen transfer (eq. 23).

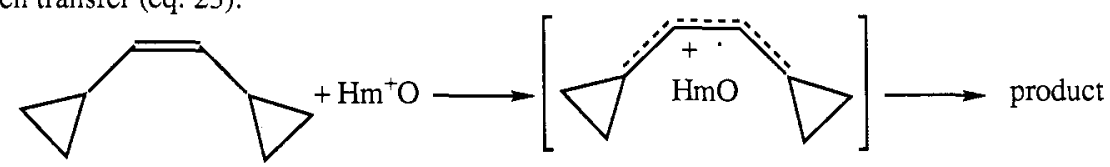


The substantial rearrangements which accompany hemin catalyzed epoxidations (ref. 50) are not consistent with a three-center transition state for that part of the reaction which leads to rearrangement (eqs. 24 and 25).

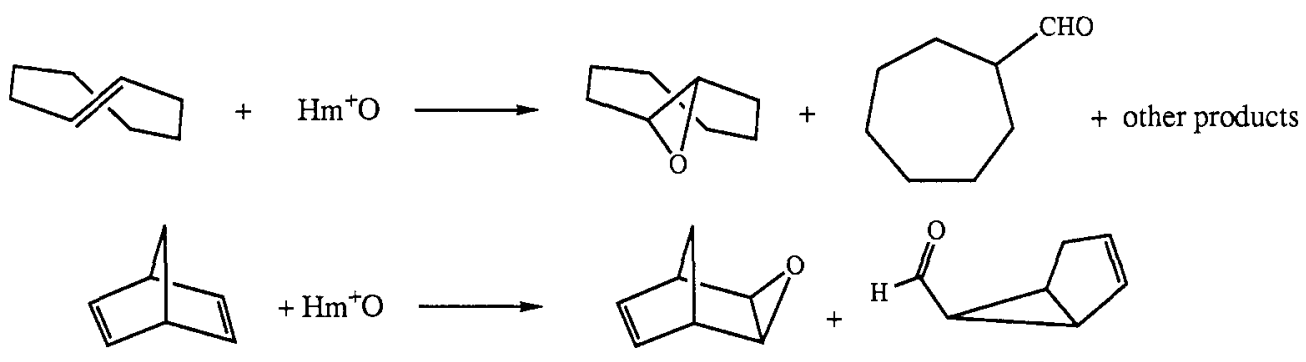

These results, along with the observation of cation-radical type rearrangements, shown in equation 26 (ref. 51),
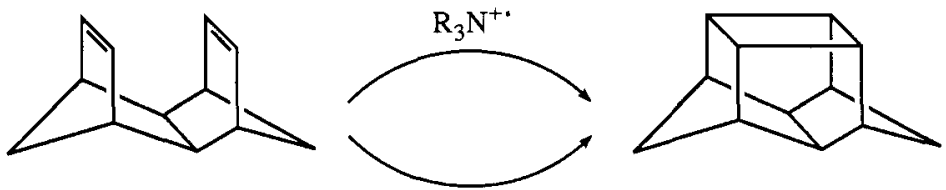

$\mathrm{Hm}^{+} \mathrm{O}$

have led to the suggestion of an electron transfer-carbocation process (ref. 50a,e).

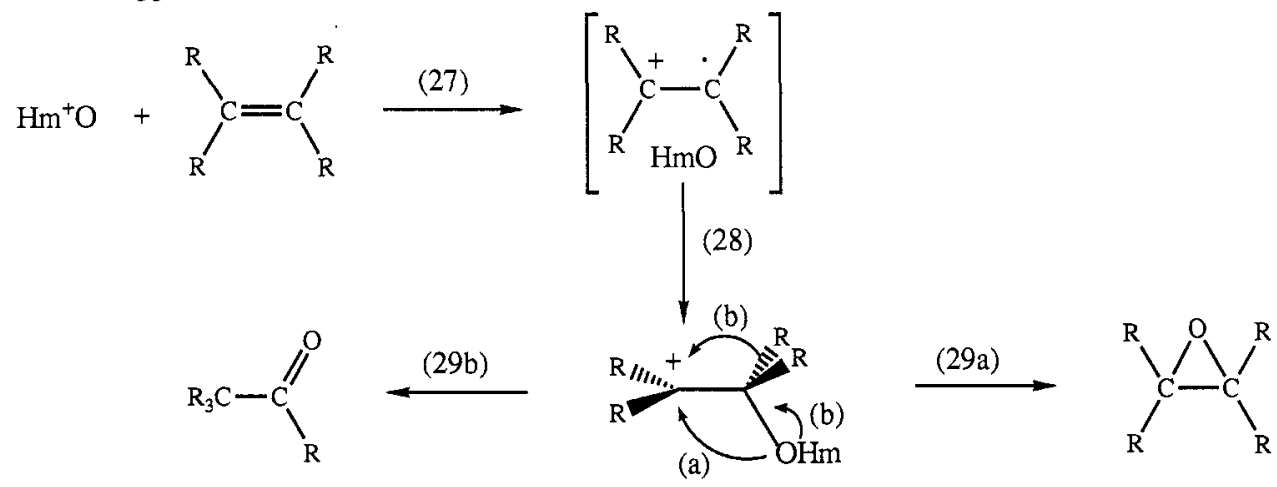

This process requires a discrete intermediate if all products are to proceed through the same initial mechanism. Groves and Watanabe have observed an intermediate species, at low temperature (ref. 52), which proceeds to product. However, the nature of this intermediate was not determined. It was suggested that a charge transfer intermediate was formed.

\section{Suicide labelling}

The observation of suicide inhibition of cytochrome P450 by 1-alkenes and acetylenes (ref. 53) and the isolation of the $\mathrm{N}$-alkylhemin produced in this process by Ortiz de Montellano (ref. 54) prompted searches for biomimetic model reactions. We discovered one such reaction which occurs when catalyst is used to epoxidize primary alkenes (ref. 55). Several other studies of this model suicide labelling process have been reported (ref. 56,57).<smiles>CN[14C](=O)N[14C](=O)NC</smiles>

Because the $\mathrm{N}$-alkylhemin has a very different spectrum from that of the hemin, we can follow the rates of $\mathrm{N}$-alkylation and epoxidation simultaneously using the spectra of the oxidant and of the developing $\mathrm{N}$-alkylhemin ( $\lambda \max =$ $435 \mathrm{~nm})$. Because both processes are controlled by the rate of production of $\mathrm{Hm}^{+} \mathrm{O}$, the rates are given by the equations below.

$$
\begin{gathered}
\mathrm{Hm}^{+}+\mathrm{OX} \stackrel{\mathrm{k}_{1}}{\longrightarrow} \mathrm{Hm}^{+} \stackrel{\mathrm{k}_{2}[\mathrm{~S}]}{\longrightarrow} \underset{\mathrm{k}_{3}[\mathrm{~S}]}{\longrightarrow} \text {-alkylhemin (Nalk) } \\
\frac{\mathrm{d}[\mathrm{ep}]}{\mathrm{dt}}=\mathrm{k}_{1} \frac{\mathrm{k}_{2}}{\mathrm{k}_{2}+\mathrm{k}_{3}}\left[\mathrm{Hm}^{+}\right][\mathrm{OX}], \frac{\mathrm{d}[\mathrm{Nalk}]}{\mathrm{dt}}=\mathrm{k}_{1} \frac{\mathrm{k}_{3}}{\mathrm{k}_{2}+\mathrm{k}_{3}}\left[\mathrm{Hm}^{+}\right][\mathrm{OX}]
\end{gathered}
$$

Clearly, the ratio of initial slopes afford the relative rates of epoxidation and $\mathrm{N}$-alkylation, the partition ratio. This is the kinetic method. Alternatively this ratio can be measured by isolating both epoxide and $\mathrm{N}$-alkyl porphyrin at the end of the reaction as others have done (ref. 56a). As with alkene competitions the two methods do not give the same result. The kinetic method gives partition numbers $\mathrm{k}_{3} / \mathrm{k} .2$ of around 50 (ref. 58) whereas the product isolation methods gives $150-800$ for similar alkenes (ref. 46a,56a,57b). 
Because the $\mathrm{N}$-alkylation is reversible, often with decomposition rate constants in excess of $0.05 \mathrm{sec}^{-1}$, the kinetic method is required if true rate constants are to be determined. If, for example we attempted to determine the partition ratios for norbornene by isolation methods e.g. $30 \mathrm{~min}$ after the reaction is finished, the ratio would be essentially infinite. Since the partition numbers are almost constant over a series of alkenes whose relative epoxidation rates vary over factor of about 100 , the $\mathrm{N}$-alkylation rate must also be very sensitive to alkene structure and follow ionization potentials. The fact that these two processes vary together suggests a common intermediate. We can now offer a common mechanism for all three processes illustrated with a 1-alkene below.

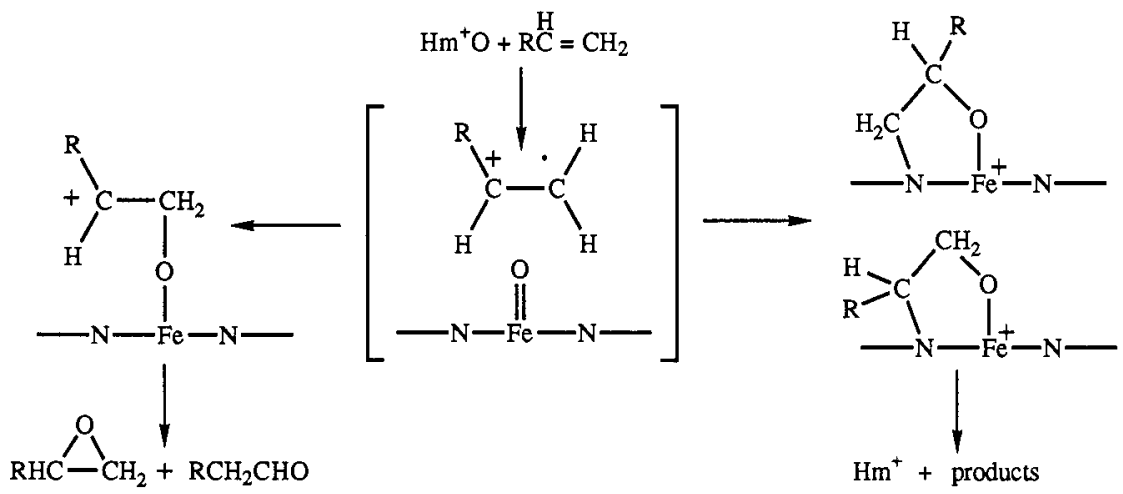

Because $\mathrm{N}$-alkylation can be accomplished with alkylating agents (ref. 59) this might occur as shown below.<smiles>CNP(=O)(N(C)C)N(C)C</smiles><smiles>CN[P+](NC)OC(C)(C)[C+](C)C</smiles><smiles>CN=[Pt+]1OC(C)(C)C(C)(C)N1C</smiles>

Alternatively, a concerted reaction of the radical cation could occur. It has been suggested that the change in rate with changing ionization potential is much smaller than can be expected for an electron transfer process (ref. 56a, $57 \mathrm{~b}$ ). This is a weakness in the argument for our proposed mechanism. We (ref. 60) and others (ref. 31a,56,57) have suggested a continuum of mechanisms varying from molecular atom transfer with unreactive alkenes to electron transfer for very reactive alkenes (those with low ionization potentials). Our data seem to suggest electron transfer for reactive alkenes such as cyclohexene or norbornene.

\section{Acknowledgements}

I am grateful to the National Science Foundation (Grant CHE-87-21364) and the National Institutes of Health (Grants HL 13581-21, DK07233-14, and RR04733-01; to my collaborators, C.K. Chang, P.S. Traylor, D. Dolphin, T. Evans, J. Ibers, R. van Eldik, and D. Magde; to my coworkers whose recent unpublished work was mentioned, D.J. Taube, J. Luo, P. Maffuid, M. McDougall, W.P. Fann, Z.Q. Tian, D. Bandyopadhyay, T. Nakano, B. Dunlap, F. Xu, K. Hill, and to the other coworkers whose names appear in the references.

\section{REFERENCES}

1. a) J.L. Martin, A. Migus, C. Poyart, Y. Lecarpentier, R. Astier, and A. Antonetti, EMBO J., 2, 1815-1819 (1983).

b) P.C. Wilkins and R. G. Wilkins, Coord. Chem. Rev., 79, 195-214 (1987).

2. a) S.E.V. Philipps, J. Mol. Biol. 142, 531-534 (1980) and references given there.

b) B. Shaanan, Nature, Lond. $296,683-684$ (1988) and references given there.

3. a) B.C. Finzel, T.L. Poulus, and J. Kraut, I. Biol. Chem., 259, 13027-13036 (1984).

b) H.B. Dunford and J.S. Stillman, Coord. Chem. Rev., 19, 187-251 (1976).

c) B. Chance, Arch. Biochem. Biophys., 37, 235-239 (1952).

d) D. Job and H.B. Dunford, Eur. J. Biochem, 66, 607-614 (1976).

e) B. Chance, Enzymes, 2, Part 2, 428-434 (1951).

4. a) J.P. Collman, Acc. Chem. Res., 10, 265-272 (1977)

b) M. Momenteau, Pure Appl. Chem. $58,1493-1502$ (1986).

c) T.G. Traylor, Acc. Chem. Res. 14, 102-109 (1981)

d) T.G. Traylor, New Aspects of Organic Chemistry I, pp 509-527, Kodansha Ltd., Tokyo (1989).

e) P.E. Ellis, Jr., J.E. Linard, T. Symanski, R.D. Jones, J.R. Budge, and F. Basolo, J. Am. Chem. Soc., 102, 1889-1896 (1980).

f) J.E. Linard, P.E. Ellis, Jr., J.R. Budge, R.D. Jones, and F. Basolo. Ibid, 102, 1896-1902 (1980).

g) D.H. Busch, L.L. Zimmer, J.J. Grzybowski, D.J. Olszanski, S.C. Jackels, R.C. Callahan, and G.C. Christoph, Proc. Natl. Acad. Sci. U.S.A., 78, 5919-5923 (1981).

h) A.R. Battersby, S.G. Hartley, and M.G. Turnbill, Tetrahedron Lett., 3169-3172 (1978).

5. H. Diekmann, C.K. Chang, and T.G. Traylor, J. Am. Chem. Soc., 93, 4068-4070 (1971). 
6. a) C.K. Chang and T.G. Traylor, J.Am. Chem. Soc. 95, 5810-5811 (1973).

b) C.K. Chang and T.G. Traylor, Proc. Nat1. Acad. Sci. U.S.A., 70, 2647-2650 (1973).

c) J.E. Baldwin and J. Huff, J. Am. Chem. Soc, 95, 5757-5758 (1973).

7. J.P. Collman, R.R. Gagne, 'T.R. Halbert, J. Marchon, and C.A. Reed, J. Am. Chem. Soc., 95, 7868-7870 (1973).

8. J. Almog, J. E. Baldwin, R.L. Dyer, and M. Peters, J. Am. Chem. Soc., 97, 226-227 (1975).

9. a) C.K. Chang and T.G. Traylor, Biochem. Biophys. Res. Commun, 62, 729-735 (1975).

b) C.K. Chang and T.G. Traylor, Proc. Natl. Acad. Sci. U.S.A., 72, 1166-1170 (1975).

10. a) T.G. Traylor, C.K. Chang, J. Geibel, A. Berzinis, T. Mincey, and J. Cannon, J. Am. Chem. Soc., 101, 6716-6731 (1979)

b) J.P. Collman, J.I. Brauman, B.L. Iverson, J.L. Sessler, R.M. Morris, and Q.H. Gibson, J.Am. Chem. Soc., 105, 3052-3064 (1983).

c) J. Mispelter, M. Momenteau, D. Lavalette, and J. Lhoste, J.Am. Chem. Soc., 105, 5165-5196 (1983)

d) M. Momenteau, J. Mispelter, B. Loock, and E. Bisagni, J. Chem. Soc. Perkin Trans. 1, 189 (1983).

11. a) E.J. Heidner, R.C. Ladner, and M.F. Perutz, J. Mol. Biol., 104, 707-711 (1976).

b) P.W. Tucker, S.E.V. Phillips, M.F. Perutz, P. Houtchens, and W.S. Caughey, Proc, Natl. Acad. Sci. U.S.A., 75, 1076-1080 (1978).

12. G.B. Jameson, F.S. Molinaro, J.A. Ibers, J.P. Collman, J.I. Brauman, E. Rose, and K.S. Suslick, L. Am. Chem. Soc., 102, 3224-3237 (1980).

13. a) S.H. Lin, N.T. Yu, J. Tame, D. Shih, P. Renaud, J. Pagnier, and K. Nagai, J. Biochem., 29, 5562-5566 (1990).

b) C. Tetreau, D. Lavallette, M. Momenteau and J.M. Lhoste, Proc. Natl. Acad. Sci. U.S.A., 84, 2267-2271 (1987)

14. a) R.H. Austin, K.W. Beeson, L. Eisenstein, H. Frauenfelder, and I.C. Gunsalus, Biochemistry, 14, 53555373 (1975).

b) N. Alberding, S.S. Chan, L. Eisenstein, H. Frauenfelder, D. Good, I.C. Gunsalus, T.M. Nordlund, M.F. Perutz, A.H. Reynolds, and L.B. Sorensen, Biochemistry, 17, 43-51 (1978).

c) D.D. Dlott, H. Frauenfelder, P. Langer, H. Roder, and E.E. Dilorio, Proc. Natl Acad. Sci. U.S.A., 80, 6239-6243 (1983).

15. a) B. Alpert, S. El Mohsni, L. Lindqvist, and F. Tfibel, Chem, Phys, Lett., 64, 11-16 (1979).

b) D.A. Duddell, R.J. Morris, and J.T. Richards, J. Chem. Soc. Chem. Commun., 75-76 (1979).

c) C.V. Shank, E.P. Ippen, and R. Bersohn, Science, 193, 50-51 (1976).

d) L.J. Nöe, W.G. Eisert, and P.M. Rentzepis, Proc. Natl. Acad. Sci. U.S.A., 75, 573-577 (1978).

16. a) J.A. Hutchinson, T.G. Traylor, and L.J. Nöe, I. Am. Chem. Soc., 104, 3221-3223 (1982),

b) T.G. Traylor, D. Magde, D.J. Taube, and K.A. Jongeward, J.Am. Chem. Soc, 109, 5864-5865 (1987).

17. J.D. Simon and K.S. Peters, Acc. Chem. Res., 17, 277-283 (1984).

18. D.K. White, J.B. Cannon, and T.G. Traylor, J.Am. Chem. Soc., 101, 2443-2454 (1979).

19. T.G. Traylor and D.V. Stynes, J. Am. Chem. Soc., 102, 5938-5939 (1980).

20 a) K.A. Jongeward, D. Magde, D.J. Taube, and T.G. Traylor, J. Biol. Chem., 263, 6027-6030 (1988).

b) D.J. Taube, unpublished results.

21. T.G. Traylor, D. Magde, D.J. Taube, and KA.. Jongeward, J. Am. Chem. Soc., submitted (1990).

22. E.F. Caldin and B. Hasinoff, J. Chem. Soc. Faraday Trans.1, 71, 515-526 (1975).

23. D.J. Taube, H. Projahn, R. van Eldik, D. Magde, and T.G. Traylor, J. Am. Chem.Soc, in press (1990).

24. a) M.C. Marden, E.S. Hazard III, and Q.H. Gibson, Biochemistry, 25, 2786-2792 (1986).

b) J.N. Moore, P.A. Hansen, and R.M. Hochstrasser, Chem. Phys. Lett., 138, 110-114 (1987).

25. T.G. Traylor, D.J. Taube, K.A. Jongeward, and D. Magde. J. Am. Chem. Soc., in press (1990).

26. In this sense, "migrational steric effects" refers to structural influence on the rates of formation or dissociation of the contact pair from solution and structural effects on bond making or bond dissociation steps would be considered separately. Since we find essentially no steric effects on bond formation, we attribute all of the "distal side steric effects" to the migrational steric effects in heme proteins and in adamantane heme cyclophane.

27. T. Koenig, Eree Radicals, p. 113, J. Wiley, New York (1973).

28. a) R.E. White and M.J. Coon, Ann. Rev. Biochem, 49, 315-321 (1980).

b) F.P. Guengerich and T.L. MacDonald, Acc. Chem. Res. 17, 9-16 (1984).

29. J.T. Groves, T.E. Nemo, and R.S. Myers, J.Am. Chem. Soc., 101, 1032-1033 (1979).

30. C.K. Chang and M.S. Kuo, J. Am. Chem. Soc. 101, 3413-3415 (1979),

31. a) D. Mansuy, P. Battioni and J.P. Battioni, Eur. J. Biochem, 184, 267-285 (1984).

b) I. Tabushi, Coord. Chem. Rev, 86, 1-2 (1988).

c) P. Ortiz de Montellano, Cytochrome P-450: Structure, Mechanism, and Biochemistry, Plenum, N.Y. (1986).

d) T.C. Bruice, Mechanistic Principles of Enzyme Activity, V. 9, p. 50, VCH Publishers (1989).

e) B. Meunier, E.-Guilmet, M.E. DeCarvalho, and R. Poilblanc, J. Am. Chem. Soc., 106, 6668-6676 (1984).

f) J.R. Lindsay-Smith and P.R. Sleath, J. Chem. Soc.. Perkin Trans. 2, 621-628 (1983).

g) J.R. Lindsay-Smith and P.R. Sleath, Ibid, 1165-1172 (1983).

h) J.P. Collman, J.I. Brauman, B. Meunier, T. Hayashi, T. Kodadek, and S.A. Raybuck, J. Am. Chem. Soc, 107, 2000-2005 (1985).

i) A.M. Khenkin and A.E. Shilov, New J.Chem., 13, 659-667 (1989)

j) D. Mansuy, Pure App. Chem., 59, 759-770 (1987).

32. a) J.T. Groves, R.C. Haushalter, M. Nakamura, T.E. Nemo, and B.J. Evans, L.Am. Chem. Soc, 103, 28842886 (1981).

b) H.J.E. Penner, E.K. Smith, T.J. McMurry, M. Renner, A.L. Balch, J.T. Groves, J.H. Dawson, and K.O. Hodgson, J. Am. Chem. Soc., 108, 7819-7825 (1986).

33. H. Sugimoto, H.S. Tung and D.T. Sawyer, J. Am. Chem. Soc., 110, 2465-2470 (1988).

34. a) P.S. Traylor, D. Dolphin, and T.G. Traylor, J. Chem. Soc. Chem Commun., 279-280 (1984).

b) T.G. Traylor and S. Tsuchiya, Inorg. Chem., 26, 1338-1339 (1987).

c) S. Tsuchiya and M. Seno, Chem. Lett., 263-266 (1989). 
35. a) T.G. Traylor, J.C. Marsters, Jr., T. Nakano, and B.E. Dunlap, J. Am. Chem. Soc., 107, 5537-5539 (1985).

b) T.G. Traylor and F. Xu, J. Am. Chem. Soc., 110, 1953-1958 (1988).

36. T.G. Traylor, K.W. Hill, S. Tsuchiya, and B.E. Dunlap, J. Am. Chem. Soc., submitted (1990).

37. a)R.D. Arasasingham, A.L. Balch, C.R. Cornman, and L. Latos-Grazynski, J. Am. Chem. Soc., 111, 43574363 (1989).

b) D. Chin, G.N. LaMar, and A.L. Balch, J. Am. Chem. Soc., 102, 5945-5947 (1980).

c) J.T. Groves, Y. Watanabe, and T.J. McMurry, J. Am. Chem. Soc., 105, 4489-4490 (1983).

d) K. Tajima, M. Shigamatsu, J. Jinno, Y. Kawano, M. Mikami, K. Ishizu, and H. Ohya-Nishiguchi, Biochem. Biophys. Res. Comm., 166, 924-926 (1980).

38. J.T. Groves and Y. Watanabe, J. Am. Chem. Soc., 110, 8443-8452 (1988).

39. a) T.G. Traylor, W.A. Lee, and D.V. Stynes, J. Am. Chem. Soc., 106, 755-764 (1984).

b) T.G. Traylor, W.A. Lee, and D.V. Stynes, Tetrahedron, 40, 553-568 (1984).

c) T.G. Traylor and J.P. Ciccone J. Am. Chem. Soc, $111,8413-8420$ (1989).

d) T.G. Traylor and F. Xu. J.Am. Chem. Soc, 112, 178-186 (1990).

40. a) $\mathrm{F}$. $\mathrm{Xu}$, unpublished results.

b) T.G. Traylor and R. Popovitz-Biro, J. Am. Chem. Soc., 110, 239-243 (1988).

41. a) W.A. Lee. Thesis, University of California, San Diego, La Jolla, California (1982).

b) W.A. Lee and T.C. Bruice, J. Am. Chem. Soc., 107, 513-514 (1985).

c) W.A. Lee, L.C. Yuan, and T.C. Bruice, J.Am. Chem. Soc., 110, 4277-4283 (1988).

42. T.L. Poulus and J. Kraut, J. Biol. Chem., 255, 8199-8205 (1980).

43. I. Fita and M.G. Rossman, J. Mol. Biol., 185, 21-27 (1985).

44. a) T.L. Poulus, B.C. Finzel, I.C. Gunsalus, G.C. Wagner, and J. Kraut, J. Biol. Chem., 260, 16122-16130 (1985).

b) T.L. Poulus, B.C. Finzel, and A.J. Howard, J. Mol. Biol., 195, 687-700 (1987).

45. a) J.R. Lindsay-Smith and P.R. Sleath, J. Chem. Soc. Perkin Trans.2, 1009-1015 (1982).

b) J.P. Collman, T. Kodadek, and J.I. Brauman, J.Am. Chem. Soc., 108, 2588-2594 (1986).

c) K. Srinivasan, P. Michaud, and J.K. Kochi, J. Am. Chem. Soc, 108, 2309-2320 (1986).

46. a) J.P. Collman, P.D. Hampton and J.I. Brauman, I. Am. Chem. Soc., 112, 2977-2986 (1990).

b) T.G. Traylor, W.-P. Fann, and D. Bandyopadhyay. J. Am. Chem. Soc., 111, 8009-8010 (1989).

c) D. Ostovic and T.C. Bruice, J. Am. Chem. Soc., 110, 6906-6908 (1988).

47. M. McDougall, unpublished results.

48. a) W. Hanstein, H.J. Berwin, and T.G. Traylor, I. Am. Chem, Soc., 92, 829-836 (1970).

b) N.A. Clinton, R.S. Brown, and T.G. Traylor, I. Am. Chem. Soc., 92. 5228-5230 (1970).

49. A.R. Bassindale and P.G. Taylor, in The Chemistry of Organic Silicon Compounds, S. Patai and Z. Rappoport, Eds., Wiley, N.Y. (1989) p. 893.

50. a) T.G. Traylor, Y. Iamamoto, and T. Nakano, J. Am. Chem. Soc., 108, 3529-3531 (1986)

b) T.G. Traylor, T. Nakano, B.E. Dunlap, P.S. Traylor, and D. Dolphin, J.Am. Chem. Soc., 108, 2782-2784 (1986).

c) R.E. Miller and F.P. Guengerich, Biochemistry, 21, 1090-1097 (1982).

d) J.T. Groves and R.S. Myers, J. Am. Chem. Soc, $105,5791-5796$ (1983).

e) D.C. Liebler and F.P. Guengerich, Biochemistry, 22, 5482-5483 (1983).

51. T.G. Traylor and A.R. Miksztal, J. Am. Chem. Soc., 109, 2770-2774 (1987).

52. J.T. Groves and Y. Watanabe, J. Am. Chem. Soc., 108, 507-508 (1986).

53. P.R. Ortiz de Montellano, Cytochrome P450 Structure, Mechanism and Biochemistry Plenum Press, New York, Chapter 8, (1986).

54. P.R. Ortiz de Montellano, H.S. Beilan, and K.L. Kunze, J. Biol Chem, 256, 6708-6713 (1981).

55. T. Mashiko, D. Dolphin, T. Nakano, and T.G. Traylor, J.Am. Chem. Soc., 107, 3735-3736 (1985).

56. a) J.P. Collman, P.D. Hampton and J.I. Brauman, J. Am. Chem. Soc., 112, 2986-2998 (1990).

b) P. Maffuid, unpublished results.

57. a) T.G. Traylor, T. Nakano, A.R. Miksztal, and B.E. Dunlap, I. Am. Chem. Soc, 109, 3625-3632 (1987).

b) D. Ostovic and T.C. Bruice, J. Am. Chem. Soc., 111, 6511-6517 (1989).

c) D. Mansuy, L. Devocelle, I. Artaud, and J.P. Battioni, Nouv, J. Chim., 9, 711-716 (1985);

d) I. Artaud, L. Devocelle, J.P. Battioni, J.P. Girault, and M. Mansuy, J. Am. Chem. Soc., 109, 3782-3783 (1987).

58. B. Dunlap. Thesis, University of California, San Diego, La Jolla, California (1987).

59. D.K. Lavallee, The Chemistry and Biochemistry of N-Substituted Porphyrins, VCH Pubs., N.Y., p.1 (1987).

60. T.G. Traylor and A.R. Miksztal. I. Am. Chem. Soc.,111, 7443-7448 (1989). 